УДК 338:43

\title{
СУЧАСНІ РЕАЛІЇ ІННОВАЦІЙНОГО РОЗВИТКУ ПІДПРИЄМСТВ АГРОБІЗНЕСУ В УКРАЇНІ
}

\section{MODERN REALITIES OF INNOVATIVE DEVELOPMENT OF AGRICULTURAL ENTERPRISES IN UKRAINE}

\author{
Савицький Едуард Едуардович \\ кандидат економічних наук, доцент, \\ ДВНЗ «Київський національний економічний університет \\ імені Вадима Гетьмана» \\ ORCID: https://orcid.org/0000-0002-1937-5828
}

\author{
Savytskyi Eduard \\ Kyiv National Economic University named after Vadym Hetman
}

\begin{abstract}
У статті досліджено сучасні реалії інноваційного розвитку підприємств агробізнесу в Україні та обґрунтовано необхідність його подальшої активізації. Визначено вагомий вплив аграрного бізнесу на позитивний розвиток економічної ситуації в державі. Розкрито сутність понять агробізнесу й інноваційного розвитку та запропоновано визначення інноваційного розвитку підприємств агробізнесу. Розкрито особливості інноваційної діяльності провідних агрохолдингів України та визначено необхідність підвищення інноваційності підприємств агробізнесу. У статті наголошується на негативному впливі пандемії COVID-19 на стан розвитку аграрного бізнесу та обґрунтовується необхідність впровадження інноваційних технологій підприємствами агробізнесу для збереження існуючих позицій в Україні та світі.
\end{abstract}

Ключові слова: агробізнес, підприємства агробізнесу, інноваційний розвиток, інноваційні технології, економіка, пандемія.

В статье исследованы современные реалии инновационного развития предприятий агробизнеса в Украине и обоснована необходимость его дальнейшей активизации. Определено существенное влияние аграрного бизнеса на позитивное развитие экономической ситуации в государстве. Раскрыта сущность понятий агробизнеса и инновационного развития и предложено определение инновационного развития предприятий агробизнеса. Раскрыты особенности инновационной деятельности ведущих агрохолдингов Украины и определена необходимость повышения инновационности предприятий агробизнеса. В статье отмечается негативное влияние пандемии COVID-19 на развитие агробизнеса и обосновывается необходимость внедрения инновационных технологий предприятиями агробизнеса для сохранения существующих позиций в Украине и мире.

Ключевые слова: агробизнес, предприятия агробизнеса, инновационное развитие, инновационные технологии, экономика, пандемия.

In the article, the author aims to determine the current state of innovative development of Ukrainian agricultural enterprises and search for problematic issues in this area by analyzing the innovativeness of these enterprises. The author emphasizes the relevance of the research topic, due to the dynamic nature of the economic situation, which is a consequence of modern changes in the world. The article emphasizes the negative impact of the COVID-19 pandemic on the state of functioning of agribusiness enterprises in Ukraine. The author attributes this to the fact that the pandemic has dramatically changed the global economic outlook, including in the field of agribusiness. The essence of agribusiness and innovative development is characterized during the research. An analysis of the activities of leading Ukrainian agricultural holdings is made, innovative technologies that are currently used in the activities of the latter are identified and ways of further development are determined. In the article the author repeatedly emphasizes the need to increase the level of innovation of agribusiness enterprises in our country. Summarizing the results of the study, the article confirms that the activities of agribusiness enterprises are an important component of the economy of Ukraine. In addition, the conclusions state that the topic of innovative development of agribusiness is especially relevant in a pandemic. It is also emphasized that due to the creation and operation of new knowledge and innovative developments, in modern conditions, agribusiness enterprises of Ukraine will be able to maintain their positions and improve their activities. According to the author, the results of the study are of practical importance for Ukrainian agribusiness enterprises, as they can increase the efficiency of their economic activity.

Keywords: agribusiness, agribusiness enterprises, innovative development, innovative technologies, economy, pandemic. 
Постановка проблеми. Динамічний характер економічної ситуації в Україні та світі змушує підприємців шукати нові можливості для розвитку свого бізнесу незалежно від сорери його фрункціонування [11]. Значною мірою це пов'язано зі встановленням карантину та запровадженням обмежувальних протиепідемічних заходів у зв'язку з поширенням гострої респіраторної хвороби COVID-19, спричиненої короновірусом SARS-CoV-2 [10]. Звісно, така ситуація внесла певний дисбаланс у функціонування кожної галузі національного господарства. У зв'язку з цим, слід зауважити, що економіка України на сьогодні переживає досить складні часи. Необхідність безперервного пристосування до постійних змін, невизначеність зовнішнього середовища, ризик втрати співробітників через вищевказану хворобу тощо - все це створює негативний вплив на економічну ситуацію країни в цілому. Безумовно, що зазначене також стосується і діяльності підприємств агробізнесу в Україні, оскільки останній $є$ не лише одним з ключових секторів економіки, але й забезпечує продовольчу безпеку держави та ряд галузей промисловості сировиною. Тому, для утримання наявних позицій і подальшого розвитку інноваційного потенціалу у сорері агробізнесу в сучасних умовах, як ніколи, слід звернути увагу на стан інноваційного розвитку.

Вищезазначене обумовлює актуальність теми дослідження та необхідність подальших наукових пошуків у сорері інноваційного розвитку українських підприємств агробізнесу.

Аналіз останніх досліджень і публікацій. Темі інноваційного розвитку агробізнесу в України присвячували свої дослідження багато відомих науковців та вчених, серед яких: Л. Андрєєва [1], В. Волощук [3], Ю. Волощук [3], А. Залєвська-Шишак [5], Ю. Кормишкін [12], Н. Король [7], В. Кудлай [8], О. Лисак [1], Є. Майовець [9], Я. Майовець [9], П. Микитюк [6], О. Шебаніна [13] та ін.

Виділення невирішених раніше частин загальної проблеми. Не зважаючи на суттєву увагу з боку науковців та вчених до вищезазначеної тематики, на сьогодні ще залишаються невирішені питання, зокрема, в частині інноваційного розвитку підприємств агробізнесу в сучасних реаліях.

Формулювання цілей статті. Метою статті $€$ визначення сучасного стану інноваційного розвитку підприємств агробізнесу в Україні.

Виклад основного матеріалу дослідження. Вивчаючи сучасні реалії інноваційного розвитку підприємств агробізнесу в Україні, доцільно на початку визначити поняття агробізнесу та інноваційного розвитку.

Слід зазначити, що в науковій літературі зустрічається декілька визначень агробізнесу. Проаналізувавши більшість 3 них, ми зупинилися на точці зору О. Журкану [4], який визначає поняття агробізнесу з двох сторін: структурності та фрункціональності. Так, структурно агробізнес - це сукупність суб'єктів підприємницької діяльності, які систематично діють на аграрному ринку. В свою чергу, фрункціонально агробізнес визначають як тип економічних відносин учасників аграрного ринку, який характеризується співпрацею, взаємною підтримкою та врахуванням економічних інтересів учасників таких відносин.

Щодо поняття інноваційного розвитку слід зазначити, що в економічній літературі представлено два основних підходи до розуміння останнього:

- предметно-технологічний або орієнтований на науковий результат, при якому інноваційний розвиток розглядається як кінцевий результат наукової чи науково-технічної діяльності;

- фрункціональний, при якому інноваційний розвиток пов'язується із функціями створення, впровадження, поширення нововведень та реалізацією інноваційних проєктів [6, c. 27].

Виходячи 3 цього, можна визначити інноваційний розвиток підприємств агробізнесу в Україні як впровадження та реалізацію інноваційних проєктів в їх господарській діяльності.

Виходячи з обраної теми дослідження, слід зазначити, що сучасний стан розвитку української економіки характеризується низькою інноваційною активністю суб'єктів господарювання. Так, лише кожне шосте підприємство в Україні здійснює інноваційну діяльність, тоді як в економічно розвинених країнах світу, таких як США та Японія, їх частка досягає 70\% від загальної кількості підприємств [3]. Наприклад, в нашій державі серед сільськогосподарських виробників найменшу питому вагу займають підприємства, діяльність яких основана на інноваційних технологіях, які можна віднести до п'ятого технологічного укладу це найбільші агрохолдинги України. 3 іншого боку фрункціонують особисті селянські і дрібні фермерські господарства, що використовують в основному ручну працю та примітивні технології другого технологічного укладу. Між ними існують різноманітні сільськогосподарські організації і великі фрермерські (селянські) господарства, чиї технології відносяться в 
основному до третього та четвертого укладів і потребують модернізації [7].

Слід звернути увагу, що в Україні інноваційний розвиток великих агропідприємств значно вищий, ніж малих. Це пов'язано, в першу чергу, 3 фрінансовими та матеріальними можливостями підприємства. Володіючи значними фрінансовими можливостями, українські агрохолдинги мають можливість впровадження новітніх інноваційних технологій, на відміну від малих підприємств агробізнесу. Останні, фрункціонують, як ми вже раніше зазначили, завдяки ручній праці аграріїв та примітивним технологіям.

Пропонуємо детальніше розглянути інноваційну діяльність провідних українських агрохолдингів.

1. UkrLandFarming - відомий своєю співпрацею зі стартапом Bitrek та іншими вітчизняними стартапами, які спеціалізуються на вимірюванні щільності ґрунту. У своїй діяльності фрірма активно використовує інновації, що сприяють зростанню продуктивності iї діяльності. Автоматизація виробництва представлена через контроль за роботою техніки, моніторинг збору врожаю, облік процесу зважування. Впровадження такого роду інновацій дає можливість заощадити близько 100 млн дол. США щорічно [5].

2. Кернел - фрінансує стартап CraftScanner, що розробляє модуль автоматичного регулювання глибини обробітку ґрунту. Разом з цим, спільно 3 львівською IT-компанією ELEKS холдинг розробляє проєкт DigitalAgriBusiness, який називає першою у світі комплексною інтелектуальною системою управління виробництвом агрокультур. Інноваційні технології також впроваджуються в напрямках обробки ґрунту, селекції та адаптації сільськогосподарських культур, контролю виконання робіт та стану посівів, управління технікою та іншими технічними ресурсами тощо. Впровадження таких інноваційних технологій дозволяє скоротити загальні витрати на $10-15 \%$ [5].

3. Миронівський хлібопродукт (МХП) - у жовтні 2017 року оголосила про запуск акселератора аграрних стартапів разом 3 UNIT. City Radar Tech. Найкращі стартапи зможуть в майбутньому співпрацювати з МХП. Холдинг вже зараз використовує декілька інноваційних розробок, зокрема, METEOTREK, спеціалізацією якого $€$ проведення технологічних операцій в сільському господарстві. Додаток MobiMill був створений задля цисрровізації бізнес-процесів рослинництва. Ще однією інновацією став Peoplemeter MHP, фрункцією якого $€$ контроль умов зберігання товарів на полицях у точках продажу. В МХП використовують такий альтернативний енергетичний ресурс, як біогаз. Компанія займає провідні позиції в країні з його виробництва [5].

4. Agroprosperis - має власне програмне забезпечення AP Agronomist, що використовується агрономами холдингу з 2015 року. АР Agronomist значно спростив і стандартизував завдання агронома, завдяки чому ефективність роботи зросла в декілька разів. Програма допомагає планувати польові роботи, сама визначає перелік необхідних операцій, а також техніки й агрегатів з урахуванням їх доступності в цей день. Завдяки актуальності та узгодженості списків полів, товарно-матеріальних цінностей, техніки й співробітників агроном працює точніше та швидше. Така технологія дозволяє успішно розвиватись, підвищуючи есрективність та керованість бізнесу [5].

5. Астарта-Київ - один 3 найбільших вертикально інтегрованих агроіндустріальних холдингів в Україні. Інноваційна аграрна компанія, яка створює єдину інфрормаційну систему управління агробізнесом - онлайн вебплаторорму 38 модулів AgriChain, інтегрує програмні додатки у власні бізнес-процеси та пропонує скористатися IT-модулями зовнішнім партнерам [2].

Виходячи 3 цього, можна стверджувати, що сучасний стан інноваційності підприємств агробізнесу в Україні знаходиться на етапі динамічного розвитку та вже має суттєві позитивні результати. Однак, слід зазначити, що показники впровадження інновацій у вітчизняних підприємствах агробізнесу все ще поступаються компаніям із розвинених країн світу.

Необхідно зауважити, що економічне зростання країни в сучасних умовах значною мірою залежить від її здатності адаптуватися до технологічних зрушень, а збільшення обігу та зростання виробництва - від впровадження інновацій [1]. Наразі, інноваційний розвиток для українського агробізнесу як ніколи важливий, оскільки з кінця 2019 року до теперішнього часу на світову та українську економіку почав здійснювати негативний вплив новий фрактор - пандемія COVID-19 та карантинні обмеження, що були введені у зв'язку з цим. Пандемія кардинально змінила глобальні економічні перспективи, особливо у сорері діяльності підприємств агробізнесу. Такими нині $€$ значне скорочення світового ВВП (більше, ніж на 5,2\%), банкрутство великої кількості суб'єктів господарювання, глобальна рецесія, втрата робочих місць, проблеми з торговель- 
ними зв'язками, зниження інвестицій та інше [14]. Виходячи з цього, слід звернути увагу, що створення та експлуатація нових знань та інноваційних розробок надасть змогу українським підприємствам агробізнесу в умовах пандемії утримувати свої позиції та фрункціонувати на належному рівні.

Висновки. Результати проведеного дослідження підтверджують, що аграрний бізнес $€$ однією з найважливіших складових економіки України. Сучасний стан інноваційності підприємств агробізнесу в Україні знаходиться на етапі динамічного розвитку та вже має суттєві позитивні результати, однак, ще поступається конкурентам із розвинених країн світу. Для виходу на якісно новий рівень українському агробізнесу слід обрати інноваційний шлях розвитку, оскільки саме інноваційні технології здатні забезпечити його успішне функціонування та можливість відповідати сучасним реаліям. Завдяки впровадженню нових технологій вдасться виявити і усунути наявні проблеми, запобігти загрозам та мінімізувати ризики на підприємстві і, як наслідок, підвищити рівень ефективності діяльності підприємств агробізнесу в Україні.

\section{СПИСОК ВИКОРИСТАНИХ ДЖЕРЕЛ:}

1. Андрєєва Л.О., Лисак О.І. Обґрунтування доцільності технологічної інновації у агробізнесі. Підприємство в аграрній сфрері: глобальні виклики та ефективний менеджмент : матеріали II Міжнар. наук.-практ. конфр. (Запоріжжя, 9-11 лют. 2021 р.). Запоріжжя : ЗНУ, 2021. С. 21-23.

2. Астарта-Київ. URL: https://astartaholding.com

3. Волощук Ю.О., Волощук В.Р. Активізація інноваційного розвитку агробізнесу. Інноваційне підприємництво: стан та перспективи розвитку агробізнесу : матеріали II Всеукр. наук.-практ. інтернет-конф. (Київ, 29-30 берез. 2017 р.). Київ : КНЕУ, 2017. С. 120-123.

4. Журкану О.М. Теоретичні основи та фрорми прояву аграрного бізнесу на регіональному рівні. Агросвіт. 2009. № 4. С. 30-34.

5. Залєвська-Шишак А.Д., Фесун Ю.А. Роль агрохолдингів у впровадженні інновацій в аграрному секторі економіки України. Ефективна економіка. 2021. № 1. URL: http://www.economy.nayka.com.ua/?op=1\&z=8540

6. Микитюк П.П., Крисько Ж.Л., Овсянюк-Бердадіна О.Ф., Скочиляс С.М. Інноваційний розвиток підприємства. Тернопіль : ПП «Принтер Інсрорм», 2015. 224 с.

7. Король Н.І. Інноваційний розвиток агробізнесу в умовах глобалізації світової економіки. Агросвіт. 2015. № 3-4. C. 71-74.

8. Кудлай В.Г. Стратегічні орієнтири розвитку агропромислового комплексу в Україні. Підприємництво в аграрній ссрері: глобальні виклики та ефективний менеджмент : матеріали II Міжнар. наук.-практ. конфр. (Запоріжжя, 9-11 лют. 2021 р.). Запоріжжя : ЗНУ, 2021. С. 87-90.

9. Майовець Є.Й., Майовець Я.М. Соціальна відповідальність у системі інноваційного розвитку агробізнесу. Вісник Львівського університету. 2020. № 59. С. 174-186.

10. Про встановлення карантину та запровадження обмежувальних протиепідемічних заходів 3 метою запобігання поширенню на території України гострої респіраторної хвороби COVID-19, спричиненої короновірусом SARS-CoV-2 : постанова Кабінету Міністрів України від 9 грудня 2020 р. № 1236. URL: https://zakon.rada.gov.ua/laws/show/1236-2020-\%D0\%BF\#Text

11. Черевко І.В. Нішевий агробізнес в Україні. Actual problems of practice and science : the IV International Science Conference (Ankara, 5-6 March 2021). Ankara, 2021. C. 31-32.

12. Шебаніна О.В., Кормишкін Ю.А. Сучасна парадигма інноваційного розвитку аграрного підприємства. Вісник аграрної науки Причорномор'я. 2019. № 3. С. 4-10.

13. Шебаніна О.В., Купчишина О.А. Державна підтримка інноваційного розвитку аграрного сектору України. Вісник ХНАУ ім. В.В. Докучаєва. 2020. № 2. С. 340-352.

14. The Global Economic Outlook During the COVID-19 Pandemic: A Changed World. URL: https://www.worldbank.org/ en/news/feature/2020/06/08/the-global-economic-outlook-during-the-covid-19-pandemic-achanged-world

\section{REFERENCES:}

1. Andrieieva L.O., Lysak,O.I. (2021) Obgruntuvannia dotsilnosti tekhnolohichnoi innovatsii u ahrobiznesi [Substantiation of the feasibility of technological innovation in agribusiness]: II Mizhnarodna naukovo-praktichna konferenciya «Pidpryiemstvo v ahrarnii sferi: hlobalni vyklyky ta efektyvnyi menedzhment» - The International Scientific and Practical Conference «Agricultural enterprise: global challenges and effective management» (Zaporozhye, February 9-11th, 2021) (pp. 21-23). Zaporizhzhia: ZNU. (in Ukrainian) 
2. Astarta-Kyiv [Astarta-Kyiv]. Available at: https://astartaholding.com/

3. Voloshchuk Yu.O., Voloshchuk V.R. (2017) Aktyvizatsiia innovatsiinoho rozvytku ahrobiznesu [Intensification of innovative development of agribusiness]. Vseukrainska naukovo-praktychna internet-konferentsiia «Innovatsiine pidpryiemnytstvo: stan ta perspektyvy rozvytku ahrobiznesu» - All-Ukrainian Scientific and Practical Internet Conference «Innovative entrepreneurship: state and prospects of agribusiness development» (Kyiv, Mart 29-30th, 2017). (pp. 120-123). Kyiv: KNEU. (in Ukrainian)

4. Zhurkanu O.M. (2009) Teoretychni osnovy ta formy proiavu ahrarnoho biznesu na rehionalnomu rivni [Theoretical bases and forms of manifestation of agrarian business at the regional level]. Ekonomika APK, no. 4, pp. 30-34.

5. Zalievska-Shyshak A.D., Fesun Yu.A. (2021) Rol ahrokholdynhiv u vprovadzhenni innovatsii v ahrarnomu sektori ekonomiky Ukrainy [The role of agricultural holdings in the implementation of Innovations in the agricultural sector of ukraine's economy]. Efektyvna ekonomika, no. 1. Available at: http://www.economy.nayka.com.ua/?op=1\&z=8540

6. Mykytiuk P.P., Krysko Zh.L., Ovsianiuk-Berdadina O.F. \& Skochylias S.M. (2015) Innovatsiinyi rozvytok pidpryiemstva [Innovative development of the enterprise]: навчальний посібник [tutorial]. Ternopil: PP «Prynter Inform», 224 p. (in Ukrainian)

7. Korol N.I. (2015) Innovatsiinyi rozvytok ahrobiznesu v umovakh hlobalizatsii svitovoi ekonomiky [Innovative development of agribusiness in context of globalization]. Ahrosvit, no. 3-4, pp. 71-74.

8. Kudlai V.H. (2021) Stratehichni oriientyry rozvytku ahropromyslovoho kompleksu v Ukraini [Strategic benchmarks for the development of the agro-industrial complex in Ukraine]: II Mizhnarodna naukovo-praktichna konferenciya «Pidpryiemstvo v ahrarnii sferi: hlobalni vyklyky ta efektyvnyi menedzhment» - The International Scientific and Practical Conference «Agricultural enterprise: global challenges and effective management» (Zaporozhye, February 9-11th, 2021) (pp. 87-90). Zaporizhzhia: ZNU. (in Ukrainian)

9. Maiovets Ye.Y., Maiovets Ya.M. (2020) Sotsialna vidpovidalnist u systemi innovatsiinoho rozvytku ahrobiznesu [Social responsibility in the system of innovative development of the agracultural business]. Visnyk Lvivskoho universytetu, no. 59, pp. 174-186.

10. Pro vstanovlennia karantynu ta zaprovadzhennia obmezhuvalnykh protyepidemichnykh zakhodiv z metoiu zapobihannia poshyrenniu na terytorii Ukrainy hostroi respiratornoi khvoroby COVID-19, sprychynenoi koronovirusom SARS-CoV-2 [On the establishment of quarantine and the introduction of restrictive anti-epidemic measures to prevent the spread of acute respiratory disease COVID-19 caused by sars-CoV-2 coronavirus in Ukraine]: postanova Kabinetu Ministriv Ukrainy vid 9 hrudnya 2020 r. № 1236. Available at: https://zakon.rada.gov.ua/laws/ show/1236-2020-\%D0\%BF\#Text (accessed 26 October 2021).

11. Cherevko I.V. (2021) Nishevyi ahrobiznes v Ukraini [Niche agribusiness in Ukraine]: IV miznarodna naukova conference «actualing problems practices i nauki» - IV International Science Conference «Actual problems of practice and science» (Ankara, March 5-6th, 2021) (pp. 31-32). Ankara. (in Ukrainian)

12. Shebanina O.V., Kormyshkin Yu.A. (2019) Suchasna paradyhma innovatsiinoho rozvytku ahrarnoho pidpryiemstva [The modern paradigm of innovative development of agricultural entrepreneurship]. Visnyk ahrarnoi nauky Prychornomor'ia, no. 3, pp. 4-10.

13. Shebanina O.V., Kupchyshyna O.A. (2020) Derzhavna pidtrymka innovatsiinoho rozvytku ahrarnoho sektoru Ukrainy [Model of innovative development of agricultural enterprises in the context of globalization]. Visnyk KhNAU im. V.V. Dokuchaieva, no. 2, pp. 340-352.

14. Hlobalnyi ekonomichnyi prohnoz pid chas pandemii COVID-19: zminy u sviti [The Global Economic Outlook During the COVID-19 Pandemic: A Changed World]. Available at: https://www.worldbank.org/en/news/ feature/2020/06/08/the-global-economic-outlook-during-the-covid-19-pandemic-achanged-world 